\title{
Fractionation of carbohydrates and nitrogenous constituents of late- crop corn silages ensiled with different specific masses
}

\section{Fracionamento dos carboidratos e dos constituintes nitrogenados de silagens de milho safrinha ensiladas com diferentes massas específicas}

\author{
Fernanda Hentz'; ;oão Pedro Velho ${ }^{2 *}$; José Laerte Nörnberg'; \\ Ione Maria Pereira Haygert-Velho²; Éderson Luis Henz"; \\ João Dionísio Henn ${ }^{5}$; Vanessa Peripolli6; Pagiel Bernardi Zardin ${ }^{7}$
}

\begin{abstract}
The present study aimed to evaluate the chemical composition of carbohydrates and nitrogenous fractions of late-crop corn silages with different specific masses (SM; 90, 134, 172, and $214 \mathrm{~kg}$ dry matter $\mathrm{m}^{-3}$ ). The silage was held in $20-\mathrm{L}$ mini-silos, and the experimental design was completely randomized, with four replications (mini-silos) per treatment. Fractionation was performed according to The Cornell Net Carbohydrate and Protein System (CNCPSv5.0). The SM of the silage significantly affected the contents of ether extract $\left(\hat{\mathrm{Y}}=1.718+0.0041 \cdot \mathrm{SM} ; \mathrm{P}=0.009 ; \mathrm{R}^{2}=39.2\right)$, soluble sugars $\left(\hat{\mathrm{Y}}=0.9502-0.003445 \cdot \mathrm{SM} ; \mathrm{P}<0.001 ; \mathrm{R}^{2}=59.9\right)$, and soluble fiber $(\hat{\mathrm{Y}}=-0.4731+0.01158 \cdot \mathrm{SM} ; \mathrm{P}=$ $\left.0.025 ; \mathrm{R}^{2}=31.2\right)$. In addition, $\mathrm{SM}$ also affected carbohydrate fraction $\mathrm{B} 1$ in a linear manner $(\hat{\mathrm{Y}}=14.88$ $\left.+0.2566 \cdot \mathrm{SM} ; \mathrm{P}=0.043 ; \mathrm{R}^{2}=38.4\right)$, whereas the remaining fractions were unaffected. Furthermore, no change was observed in total $\mathrm{N}\left(\hat{\mathrm{Y}}=2.003-0.01065 \cdot \mathrm{SM}+0.000036 \cdot \mathrm{SM}^{2} ; \mathrm{P}=0.041 ; \mathrm{R}^{2}=38.8\right)$, non-protein $\mathrm{N}\left(\hat{\mathrm{Y}}=1.436-0.01103 \cdot \mathrm{SM}+0.000036 \cdot \mathrm{SM}^{2} ; \mathrm{P}=0.060 ; \mathrm{R}^{2}=35.1\right)$, soluble $\mathrm{N}(\hat{\mathrm{Y}}=1.715$ $\left.-0.01450 \cdot \mathrm{SM}+0.00005 \cdot \mathrm{SM}^{2} ; \mathrm{P}=0.024 ; \mathrm{R}^{2}=43.8\right)$, or neutral detergent insoluble $\mathrm{N}(\hat{\mathrm{Y}}=0.4979-$ $\left.0.001057 \cdot \mathrm{SM} ; \mathrm{P}<0.001 ; \mathrm{R}^{2}=70.6\right)$. The results also contributed to the differences in fractions $\mathrm{A}(\hat{\mathrm{Y}}=$ 66.47- 0.5291.SM + 0.00174. $\left.\mathrm{SM}^{2} ; \mathrm{P}=0.095 ; \mathrm{R}^{2}=30.4\right), \mathrm{B} 2\left(\hat{\mathrm{Y}}=6.78+0.05857 \cdot \mathrm{SM} ; \mathrm{P}=0.076 ; \mathrm{R}^{2}\right.$ $=20.8)$, and $\mathrm{B} 3\left(\hat{\mathrm{Y}}=19.03-0.05565 \cdot \mathrm{SM} ; \mathrm{P}=0.018, \mathrm{R}^{2}=34,1\right)$ of the Cornell model. In the present study, differences in the compression (i.e., SM) of corn silages caused changes in the contents of soluble sugar and nitrogenous constituents; however, SM alone did not explain the entire preservation of the ensiled material.
\end{abstract}

Key words: Fiber. Lignin. Nitrogen. Starch. Sugars. Zea mays.

${ }^{1}$ Profa, Departamento de Agronomia, Universidade Federal da Fronteira Sul, UFFS, Campus de Chapecó, Chapecó, SC, Brasil. E-mail: fernanda.hentz@uffs.edu.br

2 Profs., Departamento de Zootecnia e Ciências Biológicas, Universidade Federal de Santa Maria, UFSM, Campus de Palmeira das Missões, Palmeira das Missões, RS, Brasil. E-mail: velhojp@ufsm.br; ione.h.velho@ufsm.br

${ }^{3}$ Prof., Departamento de Tecnologia e Ciência dos Alimentos, UFSM, Campus de Santa Maria, Santa Maria, RS, Brasil. E-mail: jlnornberg@gmail.com

${ }^{4}$ Discente, Curso de Mestrado do Programa de Pós-Graduação em Ciência Animal, Universidade Estadual de Londrina, UEL, Londrina, PR, Brasil. E-mail: ederhenz@gmail.com

5 Analista, Empresa Brasileira de Pesquisa Agropecuária, Embrapa Suínos e Aves, Concórdia, SC, Brasil. E-mail: joao.henn@ embrapa.br

${ }^{6}$ Prof., Instituto Federal Catarinense, IFC, Campus Avançado de Abelardo Luz, Abelardo Luz, SC, Brasil. E-mail: vanessa. peripolli@hotmail.com

7 Discente, Curso de Zootecnia, UFSM, Campus de Palmeira das Missões, Palmeira das Missões, RS, Brasil. E-mail: pagiel_ zardin@hotmail.com

* Author for correspondence 


\title{
Resumo
}

\begin{abstract}
Objetivou-se avaliar alterações bromatológicas sobre as frações glicídicas e nitrogenadas de silagens de milho "safrinha" com diferentes massas específicas (ME) no momento da ensilagem (90, 134, $172 \mathrm{e}$ $214 \mathrm{Kg}$ de $\mathrm{MS}^{-3} \mathrm{~m}^{-3}$ ). A ensilagem foi realizada em minissilos com capacidade de $20 \mathrm{~L}$. O delineamento experimental foi inteiramente casualizado com quatro repetições (minissilos) por tratamento. O fracionamento foi realizado segundo The Cornell Net Carbohydrate and Protein System (CNCPSv5.0). A ME afetou linearmente os teores de extrato etéreo $\hat{\mathrm{Y}}=1,718+0,0041 * \mathrm{ME}\left(\mathrm{P}=0,009 ; \mathrm{R}^{2}=39,2\right)$, açúcares solúveis $\hat{\mathrm{Y}}=0,9502-0,003445^{*} \mathrm{ME}\left(\mathrm{P}<0,001 ; \mathrm{R}^{2}=59,9\right)$ e fibra solúvel $\hat{\mathrm{Y}}=-0,4731+$ $0,01158^{*} \mathrm{ME}\left(\mathrm{P}=0,025 ; \mathrm{R}^{2}=31,2\right)$. Nos carboidratos, a fração $\mathrm{B} 1$ apresentou comportamento linear ascendente $\hat{Y}=14,88+0,2566^{*} \mathrm{ME}\left(\mathrm{P}=0,043 ; \mathrm{R}^{2}=38,4\right)$ com o aumento da $\mathrm{ME}$, enquanto as demais frações não foram influenciadas. Nos constituintes nitrogenados houve variação no nitrogênio total $\hat{Y}=$ $2,003-0,01065 * \mathrm{ME}+0,000036 * \mathrm{ME}^{2}\left(\mathrm{P}=0,041 ; \mathrm{R}^{2}=38,8\right)$, no nitrogênio não proteico $\hat{\mathrm{Y}}=1,436$ $0,01103 * \mathrm{ME}+0,000036 * \mathrm{ME}^{2}\left(\mathrm{P}=0,060 ; \mathrm{R}^{2}=35,1\right)$, no nitrogênio solúvel $\hat{\mathrm{Y}}=1,715-0,01450 * \mathrm{ME}$ $+0,00005^{*} \mathrm{ME}^{2}\left(\mathrm{P}=0,024 ; \mathrm{R}^{2}=43,8\right)$ e no nitrogênio insolúvel em detergente neutro $\hat{\mathrm{Y}}=0,4979$ $0,001057^{*} \mathrm{ME}\left(\mathrm{P}<0,001 ; \mathrm{R}^{2}=70,6\right)$, cujos resultados também contribuíram para as diferenças nas frações A $\hat{Y}=66,47-0,5291 * \mathrm{ME}+0,00174 * \mathrm{ME}^{2}\left(\mathrm{P}=0,095 ; \mathrm{R}^{2}=30,4\right), \mathrm{B} 2 \hat{\mathrm{Y}}=6,78+0,05857 * \mathrm{ME}$ $\left(\mathrm{P}=0,076 ; \mathrm{R}^{2}=20,8\right)$ e $\mathrm{B} 3 \hat{\mathrm{Y}}=19,03-0,05565^{*} \mathrm{ME}\left(\mathrm{P}=0,018 ; \mathrm{R}^{2}=34,1\right)$ do modelo de Cornell. $\mathrm{A}$ ME de compactação, de forma isolada, não serve para explicar, na totalidade, a preservação do material ensilado. Diferentes ME causam alterações no teor de açúcares solúveis das silagens de milho e nos constituintes nitrogenados.
\end{abstract}

Palavras-chave: Açúcares. Amido. Fibra. Lignina. Nitrogênio. Zea mays.

\section{Introduction}

Corn silage is one of the main forages fed to dairy cows in the United States (AKINS; SHAVER, 2014) and Canada (BRUNETTE et al., 2014), owing to its high dry matter production per hectare, ease of harvest, fermentation-facilitating dry matter contents, digestible neutral detergent fiber, and high concentration of net energy. Some of the milk producers in southern Brazil have also used corn silage for the same reasons, as well as because corn can be cultivated for silage production during both traditional (sowing in August-September) and late ("off-season"; sowing in December-January) growing seasons, which can improve land use efficiency by allowing the production of a second crop. Because the development of corn plants mainly depends on thermal conditions (BERGAMASCHI; MATZENAUER, 2014) and because the crop is harvested before grain maturation, corn silage can be grown in southern Brazil in extemporaneous time. However, harvest timing has been reported to influence the carbohydrate composition (VELHO et al., 2006) and $\mathrm{N}$ constituents (VELHO et al., 2008) of corn produced during the "off-season".
Furthermore, because the production of corn silage is essential for milk production, as well as the investments made during cultivation and the ensiling process, it is essential to store silage as best as possible. In particular, the correct compression of the silage is important, in order to exclude oxygen and to maintain anaerobic conditions that preserve the silage's nutritional quality (JOHNSON et al., 2002). The availability of oxygen in silos, as a result of inadequate compaction, promotes plant respiration (BORREANI et al., 2013), which is undesirable because excessive levels can reduce the energy content of the silage, lower the availability of soluble carbohydrates for fermentation, and produces excessive heat, especially in the upper layer (BORREANI; TABACCO, 2014). The availability of oxygen also promotes the activity of aerobic spoilage microorganisms, such as Clostridiuns, which form butyric acid and mediate the degradation of proteins into ammonia (DANNER et al., 2003), thus reducing the nutritional value of the silage and its voluntary intake by animals.

Higher specific mass (SM) yields better preservation of soluble carbohydrates, smaller 
proportional increases in structural carbohydrates, and lower levels of proteolysis, all of which improve the quality of the silage (VELHO et al., 2007) and reduce the amount of concentrate required to meet the nutritional requirements of animals. Therefore, the present study aimed to evaluate the chemical composition of the carbohydrates and nitrogenous fractions of late crop corn silages with different specific masses at the time of ensiling.

\section{Material and Methods}

Fieldwork was conducted in a private property in Pinhalzinho, Santa Catarina, whose county seat is $515 \mathrm{~m}$ above sea level. The soil is classified as a haplic Cambisol (EMBRAPA, 1999), and the climate is humid mesothermal, with hot summers and mean annual rainfall of 1500-2000 $\mathrm{mm}$.

We used an early-maturing corn hybrid, with semi-hard, orange grain, and sowing in the first half of January, with row spacing of $0.75 \mathrm{~m}$. No base fertilization was used, as previously tract of land was occupied by tobacco (Nicotiana tabacum L.), the culture was established with NPK fertilization, on the order of $1000 \mathrm{~kg} \mathrm{ha}^{-1}$. However, we recommend the use of fertilizer for silage production, regardless of the growing season or historic use of the land, in order to avoid the depletion of soil nutrients.

The corn plants were harvested at the end of April and ensiled at 90, 134, 172, and $214 \mathrm{~kg}$ dry matter (DM) $\mathrm{m}^{-3}$. Immediately after cutting, the plants were chopped into particles with a mean size of $2 \mathrm{~cm}$, using a stationary shredder, and transferred to mini-silos $(n=4)$, which were each constructed from three nested 9-micron plastic bags. To achieve the different levels of compaction (i.e., specific masses), trampling the bags were armed buckets of $20 \mathrm{~L}$. Then, after closing, the mini-silos were removed from the buckets and stored at room temperature, sheltered from sunlight. During the compaction process, the pre-determined levels of compaction were ensured by weighing the minisilos. After $78 \mathrm{~d}$ of ensiling, the mini-silos were opened, the upper layer of each was discarded, and the remaining silage was homogenized.

The $\mathrm{pH}$ of silages was measured, using a digital potentiometer, from juice that was obtained by pressing; and dry matter, mineral matter, ether extract, and ammonia, were determined following the recommendations of the AOAC (1995). Neutral detergent fiber corrected for ash and protein (corrected NDF; without the addition of sodium sulfite), acid detergent fiber corrected for ash and protein (corrected ADF), hemicelluloses, cellulose, and acid detergent lignin, were measured following Mertens (2002); and total N, soluble N, non-protein $\mathrm{N}$, neutral detergent insoluble $\mathrm{N}$, and acid detergent insoluble N, were measured following Licitra et al. (1996).

Furthermore, the amounts of organic acids, ethanol-insoluble residue crude protein, ethanolinsoluble residue organic matter, and soluble sugars were measured as described by Hall (2000), and starch was quantified by measuring soluble fiber, according to AOAC (1995), and using an adjusted version of the formula proposed by Hall (2000):

Starch $=($ EIROM - EIRCP $)-($ NDROM NDRCP) - Soluble fiber,

where EIRCP = ethanol-insoluble residue crude protein, EIROM = ethanol-insoluble residue organic matter, NDROM = neutral detergent residue organic matter, and NDRCP $=$ neutral detergent residue crude protein.

The fractionation of carbohydrates and nitrogenous constituents was performed as described by Sniffen et al. (1992), in which the carbohydrate fractions A, B, and C include soluble compounds with high degradation rates, compounds of moderate degradation, and non-degradable and indigestible compounds, respectively, and the nitrogenous fractions $\mathrm{A}, \mathrm{B}$, and $\mathrm{C}$ include nonprotein $\mathrm{N}$, which is high speed in the rumen, true proteins with different ruminal degradation rates, and acid detergent insoluble proteins, which are indigestible, respectively. 
The design was completely randomized with four replications (mini-silos) per treatment, and the data were submitted to regression analysis (PROC REG), using the SAS statistical software version 8.2 (SAS, 2001).

\section{Results and Discussion}

Despite the wide gap between the lowest (90 $\mathrm{kg} \mathrm{DM} \mathrm{m} \mathrm{m}^{-3}$ ) and the highest (216 $\mathrm{kg} \mathrm{DM} \mathrm{m}^{-3}$ ) SM treatments, there was no difference in DM content between the treatments $(\mathrm{P}=0.54$; Table 1$)$. Generally, lower SM increases the duration of plant respiration and aerobic microbial degradation, the greater length of oxygen in the silo, which could decrease the DM for losses in silage. Perhaps, the similarity in DM values can be explained by the construction of the mini-silos, which prevented airflow during the storage period, a condition that does not occur in field conditions. Thus, the data from the present study suggest that the DM of low-SM silages could be preserved by maintaining anaerobic conditions.

Table 1. Effect of specific mass on the various parameters of silage produced from second-season corn in southern Brazil.

\begin{tabular}{|c|c|c|c|c|c|}
\hline \multirow{2}{*}{ Parameter } & \multirow{2}{*}{ Statistics } & \multicolumn{4}{|c|}{ Specific masses $\left(\mathrm{kg} \mathrm{DM} \mathrm{m}^{-3}\right)$} \\
\hline & & 90 & 134 & 172 & 216 \\
\hline \multirow{2}{*}{$\begin{array}{l}\text { Specific masses } \\
\left(\mathrm{kg} \mathrm{NM} \mathrm{m}^{-3}\right)\end{array}$} & Mean \pm SE & $296 \pm 2.39$ & $430 \pm 1.05$ & $562 \pm 5.95$ & $701 \pm 9.44$ \\
\hline & Regression & \multicolumn{4}{|c|}{ Not analyzed } \\
\hline \multirow{2}{*}{$\begin{array}{c}\text { Dry matter } \\
(\% \mathrm{NM})\end{array}$} & Mean \pm SE & $30.4 \pm 0.27$ & $31.1 \pm 0.28$ & $30.5 \pm 0.20$ & $30.8 \pm 0.27$ \\
\hline & Regression & \multicolumn{4}{|c|}{$\hat{\mathrm{Y}}=30.42\left(\mathrm{P}=0.542 ; \mathrm{R}^{2}=2.7\right)$} \\
\hline \multirow{2}{*}{$\begin{array}{l}\text { Specific masses } \\
\left(\mathrm{kg} \mathrm{DM} \mathrm{m}^{-3}\right)\end{array}$} & Mean \pm SE & $90 \pm 0.65$ & $134 \pm 1.41$ & $172 \pm 2.80$ & $216 \pm 1.50$ \\
\hline & Regression & \multicolumn{4}{|c|}{ Not analyzed } \\
\hline \multirow{2}{*}{$\begin{array}{l}\text { Organic matter } \\
(\% \mathrm{DM})\end{array}$} & Mean \pm SE & $95.9 \pm 0.03$ & $96.0 \pm 0.18$ & $96.0 \pm 0.24$ & $95.9 \pm 0.22$ \\
\hline & Regression & \multicolumn{4}{|c|}{$\hat{\mathrm{Y}}=95.94\left(\mathrm{P}=0.948 ; \mathrm{R}^{2}=0.00\right)$} \\
\hline \multirow{2}{*}{$\begin{array}{c}\text { Ether extract } \\
(\% \mathrm{DM})\end{array}$} & Mean \pm SE & $2.0 \pm 0.10$ & $2.4 \pm 0.07$ & $2.5 \pm 0.14$ & $2.5 \pm 0.15$ \\
\hline & Regression & \multicolumn{4}{|c|}{$\hat{\mathrm{Y}}=1.718+0.0041 \cdot \mathrm{SM}\left(\mathrm{P}=0.009 ; \mathrm{R}^{2}=39.2\right)$} \\
\hline \multirow{2}{*}{$\mathrm{pH}$} & Mean \pm SE & $3.7 \pm 0.02$ & $3.8 \pm 0.04$ & $3.8 \pm 0.06$ & $3.7 \pm 0.00$ \\
\hline & Regression & \multicolumn{4}{|c|}{$\hat{\mathrm{Y}}=3.803\left(\mathrm{P}=0.513 ; \mathrm{R}^{2}=3.1\right)$} \\
\hline \multirow{2}{*}{$\begin{array}{c}\text { Total carbohydrate } \\
(\% \mathrm{DM})\end{array}$} & Mean \pm SE & $85.6 \pm 0.51$ & $85.7 \pm 0.15$ & $86.0 \pm 0.48$ & $84.6 \pm 0.53$ \\
\hline & Regression & \multicolumn{4}{|c|}{$\hat{\mathrm{Y}}=86.54\left(\mathrm{P}=0.189 ; \mathrm{R}^{2}=12.0\right)$} \\
\hline \multirow{2}{*}{$\begin{array}{c}\text { Nonfiber carbohydrates } \\
(\% \mathrm{DM})\end{array}$} & Mean \pm SE & $41.7 \pm 0.62$ & $46.0 \pm 0.52$ & $44.8 \pm 0.68$ & $43.6 \pm 0.54$ \\
\hline & Regression & \multicolumn{4}{|c|}{$\hat{\mathrm{Y}}=42.28\left(\mathrm{P}=0.300 ; \mathrm{R}^{2}=7.7\right)$} \\
\hline
\end{tabular}

$\mathrm{NM}=$ Natural matter; $\mathrm{DM}=$ Dry matter.

However, in practice, interactions occur between compacted silage material and the porosity of the materials lining the silo (e.g., concrete, plastic film). Problems occurred on the physical parameters (particle size and compression) will not be solved after the ready silage (JOBIM et al., 2007). For example, Neumann et al. (2007) evaluated the effect of particle size (0.2-0.6 and 1.0-2.0 cm), cutting height (15 and $39 \mathrm{~cm}$ ), and silo type (trench and laboratory PVC) on silage compaction and found that both particle size and silo type had significant effects $(\mathrm{P}<0.05)$, with higher SM recorded in the laboratory silos. These authors observed that laboratory silos failed to allow measuring the parameters in the same magnitude as in conventional silos (trench or surface), but allow for the comparison of treatments. In the present study, the methodology of mini-silos has shown that the maintenance of anaerobiosis is an essential factor for the preservation of stored material and 
that the maintenance of anaerobic conditions is not exclusively associated with SM.

The $\mathrm{pH}$ values observed in the present study were appropriate, since preserving forage for silage occurs in acidic medium. Decreases in $\mathrm{pH}$ from the fermentation of the ensiled forage reduced the proteolytic activity of plant enzymes and terminates the growth of undesirable anaerobic microorganisms, especially enterobacteria and clostridia (MUCK; BOLSEN, 1991).

There was no difference $(\mathrm{P}=0.19)$ in the total carbohydrates (TC) of silage from the different treatments, whose average grades are close to most of the values reported by Rabelo et al. (2014), Tres et al. (2014), Gonçalves et al. (2015), and Moro et al. (2015), whereas in corn silage, the proportions of mineral matter, $\mathrm{CP}$, and ether extract are relatively constant. There was also no difference $(\mathrm{P}=0.30)$ in the non-fiber carbohydrates (NFC) of the treatments.

There was no difference $(\mathrm{P}=0.75)$ in the estimated organic acid content of silage from the different treatments, either (Table 2). Silage suitable fermentation process has 6 to $8 \%$ of the DM lactic acid, less than $2 \%$ of the DM acetic acid, from 0 to $1 \%$ of the DM propionic acid and $<0.1 \%$ of the DM for butyric acid (FERREIRA, 2001). There is variation in the levels of organic acids in silages. For example, Hall (2000) cites mean values of $8 \%$, but most of the literature in this fraction is not more than $12 \%$ of the DM.

Table 2. Effect of specific mass on the various parameters of silage produced from second-season corn in southern Brazil, as recommended by Hall (2000).

\begin{tabular}{|c|c|c|c|c|c|}
\hline \multirow{2}{*}{ Parameter } & \multirow{2}{*}{ Statistics } & \multicolumn{4}{|c|}{ Specific masses $\left(\mathrm{kg} \mathrm{DM} \mathrm{m}^{-3}\right)$} \\
\hline & & 90 & 134 & 172 & 216 \\
\hline \multirow{2}{*}{$\begin{array}{c}\text { Organic acids } \\
(\% \mathrm{DM})\end{array}$} & Mean \pm SE & $9.7 \pm 0.78$ & $8.7 \pm 1.10$ & $10.2 \pm 0.36$ & $9.6 \pm 0.69$ \\
\hline & Regression & \multicolumn{4}{|c|}{$\hat{\mathrm{Y}}=9.148\left(\mathrm{P}=0.749 ; \mathrm{R}^{2}=0.8\right)$} \\
\hline \multirow{2}{*}{$\begin{array}{c}\text { Soluble sugars } \\
(\% \mathrm{DM})\end{array}$} & Mean \pm SE & $0.60 \pm 0.08$ & $0.54 \pm 0.09$ & $0.37 \pm 0.01$ & $0.18 \pm 0.07$ \\
\hline & Regression & \multicolumn{4}{|c|}{$\hat{\mathrm{Y}}=0.9502-0.003445 \cdot \mathrm{SM}\left(\mathrm{P}<0.001 ; \mathrm{R}^{2}=59.9\right)$} \\
\hline \multirow{2}{*}{$\begin{array}{l}\text { EIROM } \\
(\% \text { DM) } \\
\end{array}$} & Mean \pm SE & $79.0 \pm 0.64$ & $80.1 \pm 0.88$ & $79.0 \pm 0.36$ & $78.1 \pm 0.92$ \\
\hline & Regression & \multicolumn{4}{|c|}{$\hat{\mathrm{Y}}=80.43\left(\mathrm{P}=0.275 ; \mathrm{R}^{2}=8.4\right)$} \\
\hline \multirow{2}{*}{$\begin{array}{c}\text { Soluble fiber } \\
(\% \mathrm{DM})\end{array}$} & Mean \pm SE & $0.5 \pm 0.14$ & $1.4 \pm 0.70$ & $1.1 \pm 0.39$ & $2.2 \pm 0.26$ \\
\hline & Regression & \multicolumn{4}{|c|}{$\hat{\mathrm{Y}}=-0.4731+0.01158 \cdot \mathrm{SM}\left(\mathrm{P}=0.025 ; \mathrm{R}^{2}=31.2\right)$} \\
\hline \multirow{2}{*}{$\begin{array}{c}\text { EIRCP } \\
(\% \text { DM })\end{array}$} & Mean \pm SE & $3.7 \pm 0.55$ & $3.6 \pm 0.07$ & $3.6 \pm 0.25$ & $3.3 \pm 0.10$ \\
\hline & Regression & \multicolumn{4}{|c|}{$\hat{\mathrm{Y}}=3.995\left(\mathrm{P}=0.366 ; \mathrm{R}^{2}=5.9\right)$} \\
\hline \multirow{2}{*}{$\begin{array}{l}\text { Starch } \\
(\% \mathrm{DM})\end{array}$} & Mean \pm SE & $30.9 \pm 0.94$ & $35.3 \pm 1.26$ & $33.1 \pm 1.14$ & $31.6 \pm 0.45$ \\
\hline & Regression & \multicolumn{4}{|c|}{$\hat{\mathrm{Y}}=32.65\left(\mathrm{P}=0.970 ; \mathrm{R}^{2}=0.0\right)$} \\
\hline
\end{tabular}

$\mathrm{DM}=$ Dry matter; EIROM $=$ Ethanol-insoluble residue organic matter; EIRCP $=$ Ethanol-insoluble residue crude protein.

There was a linear decrease $(\mathrm{P}<0.01)$ in the levels of soluble sugars, as SM increased. The value of $0.18 \%$ was below the range of 0.3 to $4.7 \%$ and mean of $2 \%$ DM, reported by Hall (2000). This low value indicates that the soluble sugars were nearly exhausted by the microorganisms present in the micro-silos, which is desirable for the proper preservation of forage, contributing to the observed low values of $\mathrm{pH}$ (Table 1). The determination of ethanol-insoluble residue organic matter includes the extraction of simple sugars, oligosaccharides, and other low molecular weight substances (HALL et al., 1997). In the present study, the ethanol-insoluble residue organic matter fraction of the silages was not affected by SM $(\mathrm{P}=0.27)$, which indicated the absence of degradation of carbohydrates that are needed as a source of energy for microbial protein synthesis. 
To measure soluble fiber content, a combination of enzymes and various buffer solutions is required to remove starch and a portion of the proteins. This fraction consists of pectin, beta-glucans, gums, mucilages, and some hemicelluloses (WALKER, 1993). This fraction increased significantly $(\mathrm{P}=$ 0.025 ) with increases in SM. The ethanol-insoluble residue crude protein, which consists of peptides, true proteins, and cell wall-bound proteins and is insoluble in $80 \%$ ethanol (HALL et al., 1997), was not affected by SM $(\mathrm{P}=0.37)$.

Specific mass also failed to influence the starch content of the silage ( $\mathrm{P}=0.97)$; however, this was expected, since fermentation microbes prefer low molecular weight carbohydrates, such as soluble sugars. Di Marco et al. (2002) reported a starch content of $28 \%$ starch in milky/dough-stage corn silage grain produced in Argentina (SM: $179 \mathrm{~kg}$ $\mathrm{DM} \mathrm{m}^{-3}$ ). These authors attributed this result to the appropriate cultural practices associated with irrigation; however, despite that the corn plants in the present study were not irrigated checked starch values, the starch content of the silages was higher (Table 2), which can also be attributed to appropriate cultural management, especially in the decline in temperature from seeding (January) to harvest the plants (April).

Van Gastelen et al. (2015) analyzed the replacement of corn silage with starchless grass silage on ruminal volatile fatty acid concentration, $\mathrm{pH}$, and methane $\left(\mathrm{CH}_{4}\right)$ mitigation. The authors reported that increasing proportions of corn silage resulted in linear decreases in NDF intake $(\mathrm{P}<$ $0.001)$ and $\mathrm{CP}(\mathrm{P}=0.002)$ and linearly increases in starch intake $(\mathrm{P}<0.001)$, whereas $\mathrm{CH}_{4}$ emission decreased in a quadratic manner $(\mathrm{P}<0.001)$ and decreased linearly $(\mathrm{P}=0.010)$ when expressed as g $\mathrm{CH}_{4} \mathrm{~kg}^{-1} \mathrm{DM}$ intake. Thus, replacing starchless grass silage with corn silage is an effective strategy for reducing the production of enteric $\mathrm{CH}_{4}$ without adversely affecting the performance of dairy cows, although the maximum level of starch should be limited. These results can be explained by the higher quality of corn plants, with more appropriate DM contents than other silage grasses. Importantly, the results obtained by Van Gastelen et al. (2015) demonstrate the potential of Brazilian corn silage to simultaneously increase animal efficiency and reduce greenhouse gasses, the latter being a major objective of the 2015 Paris Climate Conference (COP 21). Therefore, it is crucial that Brazil allocate more financial resources to research on the production, handling, and use of conserved forage (silage and hay), as well as on the potential beneficial and deleterious environmental impacts of such processes.

Meanwhile, corrected NDF, corrected ADF, hemicelluloses, cellulose, and lignin were not affected by SM (Table 3), and the corrected NDF values indicated the great quality of the secondcrop corn silage produced in the present study, compared to $50 \%$ reported by Velho et al. (2007). The levels of starch and corrected NDF observed in the present study demonstrate the need for more research in southern Brazil, in order to determine the effect of temperature on the deposition and composition of carbohydrates and why it is occurring currently increasing milk crop-cattle integration the establishment of new industrial dairy plants in Rio Grande do Sul and Santa Catarina. Therefore, second-crop corn silage may be used to improve land use and to help minimize the amount of concentrate used the diets of dairy cows and beef steers. However, owing to the frequency of frost in southern Brazil, so that the produced silage submit appropriate conditions, sowing should not be performed beyond the first half of January. Otherwise, the risks of financial loss and metabolic disorders in animals, owing to poor quality forages, are higher.

Lignin is one of the main factors limiting the degradability of cell walls (VAN SOEST, 1994), and thus the time required for its digestion. The lignin values observed in the present study were higher than those of "normal" (2.6\% DM, on average) corn silages (32 to $38 \% \mathrm{DM}$ ) (NRC, 2001). 
Table 3. Effect of specific mass on the cell wall fractions of silage produced from second-season corn in southern Brazil.

\begin{tabular}{|c|c|c|c|c|c|}
\hline \multirow{2}{*}{ Parameter } & \multirow{2}{*}{ Statistics } & \multicolumn{4}{|c|}{ Specific masses $\left(\mathrm{kg} \mathrm{DM} \mathrm{m}^{-3}\right)$} \\
\hline & & 90 & 134 & 172 & 216 \\
\hline \multirow{2}{*}{$\begin{array}{l}\text { NDFap } \\
(\% \text { DM) }\end{array}$} & Mean \pm SE & $44.0 \pm 0.49$ & $39.7 \pm 0.39$ & $41.2 \pm 1.16$ & $41.0 \pm 1.03$ \\
\hline & Regression & \multicolumn{4}{|c|}{$\hat{\mathrm{Y}}=41.45\left(\mathrm{P}=0.122 ; \mathrm{R}^{2}=16.2\right)$} \\
\hline \multirow{2}{*}{$\begin{array}{l}\text { ADFap } \\
(\% \text { DM })\end{array}$} & Mean \pm SE & $20.8 \pm 1.71$ & $21.8 \pm 0.31$ & $17.2 \pm 1.36$ & $19.1 \pm 1.28$ \\
\hline & Regression & \multicolumn{4}{|c|}{$\hat{\mathrm{Y}}=19.71\left(\mathrm{P}=0.154 ; \mathrm{R}^{2}=14.0\right)$} \\
\hline \multirow{2}{*}{$\begin{array}{c}\text { Hemicelluloses } \\
(\% \mathrm{DM})\end{array}$} & Mean \pm SE & $24.2 \pm 1.49$ & $19.0 \pm 0.11$ & $24.8 \pm 1.05$ & $22.4 \pm 1.76$ \\
\hline & Regression & \multicolumn{4}{|c|}{$\hat{\mathrm{Y}}=22.59\left(\mathrm{P}=0.986 ; \mathrm{R}^{2}=0.0\right)$} \\
\hline \multirow{2}{*}{$\begin{array}{c}\text { Cellulose } \\
(\% \mathrm{DM})\end{array}$} & Mean \pm SE & $20.8 \pm 0.76$ & $20.6 \pm 0.82$ & $20.4 \pm 1.68$ & $18.0 \pm 1.24$ \\
\hline & Regression & \multicolumn{4}{|c|}{$\hat{\mathrm{Y}}=19.95\left(\mathrm{P}=0.115 ; \mathrm{R}^{2}=16.8\right)$} \\
\hline \multirow{2}{*}{$\begin{array}{l}\text { Lignin } \\
(\% \mathrm{DM})\end{array}$} & Mean \pm SE & $7.0 \pm 1.04$ & $6.2 \pm 0.23$ & $5.8 \pm 0.15$ & $5.6 \pm 0.88$ \\
\hline & Regression & \multicolumn{4}{|c|}{$\hat{\mathrm{Y}}=6.15\left(\mathrm{P}=0.133 ; \mathrm{R}^{2}=15.3\right)$} \\
\hline
\end{tabular}

$\mathrm{DM}=$ Dry matter; NDFap $=$ Neutral detergent fiber content corrected for ash and protein content; ADFap $=$ Acid detergent fiber content corrected for ash and protein content.

The carbohydrate fraction A was not influenced by $\operatorname{SM}(\mathrm{P}=0.12$; Table 4$)$, although the soluble sugars content was different $(\mathrm{P}<0.01)$, probably because soluble sugars were expressed as a percentage of DM, whereas the carbohydrate fraction A was expressed as a percentage of total carbohydrates. Senger et al. (2005) found that silage with an SM of $174 \mathrm{~kg} \mathrm{DM} \mathrm{m}^{-3}$ yielded 4.7 percentage units more fraction A than silage with an SM of $99 \mathrm{~kg} \mathrm{DM} \mathrm{m}^{-3}$. Most of the SM treatments, whose original material possessed $11.2 \%$ of this fraction. The contents of carbohydrate fraction A observed in the silage of the present study are higher than the those typically reported in the Brazilian literature, which suggests that the difference resulted from cooler temperatures under which the corn in the present study was grown. However, further studies are needed to fully assess this hypothesis. The compounds included in carbohydrate fraction A contribute to the growth of rumen microorganisms.

Table 4. Effect of specific mass on the carbohydrate fractions of silage produced from second-season corn in southern Brazil.

\begin{tabular}{cccccc}
\hline \multirow{2}{*}{ Parameter } & \multirow{2}{*}{ Statistics } & \multicolumn{4}{c}{ Specific masses $\left(\mathrm{kg} \mathrm{DM} \mathrm{m}^{-3}\right)$} \\
\cline { 3 - 5 } & & 90 & 134 & 172 & 216 \\
\hline Fraction $\mathrm{A}$ & Mean $\pm \mathrm{SE}$ & $17.8 \pm 0.85$ & $18.4 \pm 1.63$ & $19.0 \pm 0.36$ & $20.0 \pm 0.90$ \\
$(\% \mathrm{TC})$ & Regression & & $\hat{\mathrm{Y}}=18.78\left(\mathrm{P}=0.119 ; \mathrm{R}^{2}=16.4\right)$ \\
\hline Fraction B1 & Mean $\pm \mathrm{SE}$ & $30.9 \pm 0.94$ & $35.3 \pm 1.26$ & $33.1 \pm 1.14$ & $31.6 \pm 0.45$ \\
$(\% \mathrm{TC})$ & Regression & \multicolumn{3}{c}{$\hat{\mathrm{Y}}=14.88+0.2566 \cdot \mathrm{SM}\left(\mathrm{P}=0.043 ; \mathrm{R}^{2}=38.4\right)$} \\
\hline Fraction B2 & Mean $\pm \mathrm{SE}$ & $31.7 \pm 2.64$ & $28.9 \pm 0.90$ & $31.7 \pm 0.97$ & $32.5 \pm 3.33$ \\
$(\%$ TC $)$ & Regression & & $\hat{\mathrm{Y}}=31.21\left(\mathrm{P}=0.612 ; \mathrm{R}^{2}=1.9\right)$ & \\
\hline Fraction C & Mean $\pm \mathrm{SE}$ & $19.6 \pm 2.96$ & $17.4 \pm 0.65$ & $16.2 \pm 0.37$ & $15.9 \pm 2.55$ \\
$(\% \mathrm{TC})$ & Regression & & $\hat{\mathrm{Y}}=17.28\left(\mathrm{P}=0.159 ; \mathrm{R}^{2}=13.7\right)$ \\
\end{tabular}

$\mathrm{DM}=$ Dry matter; $\mathrm{TC}=$ Total carbohydrates

Meanwhile, carbohydrate fraction B1, which is mainly composed of starch in corn silage, increased linearly with SM. Along with the results observed for fraction $\mathrm{A}$, this pattern was different than that observed for starch, probably because starch was expressed as a percentage of DM, whereas the fractions A and B1 of carbohydrates are expressed as a percentage of total carbohydrates. However, 
regardless of SM, the starch content was high. The levels of B2-fraction carbohydrates, which possess variable degradation rates that are lower than those of B1 carbohydrates, were not affected by SM (P > $0.05)$. The values found in the present study were lower than the average values of 44.7, 50.7, and $52.2 \%$ reported by Senger et al. (2005), Cabral et al. (2000), and Velho et al. (2007), respectively. However, carbohydrate fraction $\mathrm{C}$, which is the indigestible portion of carbohydrates, was not affected by SM and was higher than the average values 10 and $7.09 \%$ reported by Senger et al. (2005) and Velho et al. (2007), respectively.

The average values of total $\mathrm{N}$, non-protein $\mathrm{N}$, soluble $\mathrm{N}$, and neutral detergent insoluble $\mathrm{N}$ exhibited quadratic relationships with SM (Table 5). As the corn silage is a bulky low level of total $\mathrm{N}$ and its fractions also suffer few variations, it is possible precision and accuracy in the results generated, making it possible to detect small statistical differences as was the case. However, these differences do not have biological importance, since it will be necessary to add other ingredients to provide ammonia and amino acids to the rumen microflora and because the determination coefficients are considered low, in relation to the effect of treatments on such variables. The unavailable $\mathrm{N}$ fraction (i.e., acid detergent insoluble N) was not significantly affected by the treatments. The concentration of ammonia $\mathrm{N}$, in relation to total $\mathrm{N}$, was considered low, when compared to the values of 7.4 and $3.84 \%$ reported by Senger et al. (2005) and Velho et al. (2007), respectively, thus indicating that the fermentation was adequate. The ammonia $\mathrm{N}$ content of silage indicates the magnitude of clostridia activity, since it is only produced in small amounts by other microorganisms in silage and plant enzymes (JOBIM et al., 2005).

Table 5. Effect of specific mass on the nitrogenous constituents of silage produced from second-season corn in southern Brazil.

\begin{tabular}{|c|c|c|c|c|c|}
\hline \multirow{2}{*}{ Parameter } & \multirow{2}{*}{ Statistics } & \multicolumn{4}{|c|}{ Specific masses $\left(\mathrm{kg} \mathrm{DM} \mathrm{m}^{-3}\right)$} \\
\hline & & 90 & 134 & 172 & 216 \\
\hline \multirow{2}{*}{$\begin{array}{l}\text { Total nitrogen } \\
(\% \mathrm{DM})\end{array}$} & Mean \pm SE & $1.3 \pm 0.07$ & $1.3 \pm 0.02$ & $1.2 \pm 0.04$ & $1.4 \pm 0.05$ \\
\hline & Regression & \multicolumn{4}{|c|}{$\hat{\mathrm{Y}}=2.003-0.01065 \cdot \mathrm{SM}+0.000036 \cdot \mathrm{ME}^{2}\left(\mathrm{P}=0.041 ; \mathrm{R}^{2}=38.8\right)$} \\
\hline \multirow{2}{*}{$\begin{array}{c}\text { Non-protein nitrogen } \\
(\% \mathrm{DM})\end{array}$} & Mean \pm SE & $0.74 \pm 0.07$ & $0.57 \pm 0.02$ & $0.64 \pm 0.05$ & $0.72 \pm 0.04$ \\
\hline & Regression & \multicolumn{4}{|c|}{$\hat{\mathrm{Y}}=1.436-0.01103 \cdot \mathrm{SM}+0.000036 \cdot \mathrm{ME}^{2}\left(\mathrm{P}=0.060 ; \mathrm{R}^{2}=35.1\right)$} \\
\hline \multirow{2}{*}{$\begin{array}{l}\text { Soluble nitrogen } \\
\text { (\% DM) }\end{array}$} & Mean \pm SE & $0.80 \pm 0.08$ & $0.69 \pm 0.04$ & $0.66 \pm 0.05$ & $0.90 \pm 0.06$ \\
\hline & Regression & \multicolumn{4}{|c|}{$\hat{\mathrm{Y}}=1.715-0.01450 \cdot \mathrm{SM}+0.00005 \cdot \mathrm{ME}^{2}\left(\mathrm{P}=0.024 ; \mathrm{R}^{2}=43.8\right)$} \\
\hline \multirow{2}{*}{$\begin{array}{l}\text { NDIN } \\
(\% \text { DM })\end{array}$} & Mean \pm SE & $0.39 \pm 0.01$ & $0.35 \pm 0.00$ & $0.36 \pm 0.00$ & $0.24 \pm 0.00$ \\
\hline & Regression & \multicolumn{4}{|c|}{$\hat{\mathrm{Y}}=0.4979-0.001057 \cdot \mathrm{SM}\left(\mathrm{P}<0.001 ; \mathrm{R}^{2}=70.6\right)$} \\
\hline \multirow{2}{*}{$\begin{array}{c}\text { ADIN } \\
(\% \text { DM })\end{array}$} & Mean \pm SE & $0.23 \pm 0.01$ & $0.18 \pm 0.02$ & $0.22 \pm 0.03$ & $0.16 \pm 0.00$ \\
\hline & Regression & \multicolumn{4}{|c|}{$\hat{\mathrm{Y}}=0.20\left(\mathrm{P}=0.176 ; \mathrm{R}^{2}=12.6\right)$} \\
\hline \multirow{2}{*}{$\begin{array}{c}\text { Ammoniacal nitrogen } \\
(\% \mathrm{TN})\end{array}$} & Mean \pm SE & $2.60 \pm 0.18$ & $2.80 \pm 0.11$ & $3.03 \pm 0.24$ & $2.78 \pm 0.22$ \\
\hline & Regression & \multicolumn{4}{|c|}{$\hat{\mathrm{Y}}=2.80\left(\mathrm{P}=0.402 ; \mathrm{R}^{2}=5.1\right)$} \\
\hline
\end{tabular}

$\mathrm{DM}=$ Dry matter; $\mathrm{TN}=$ Total nitrogen; $\mathrm{NDIN}=$ Neutral detergent insoluble nitrogen; ADIN = Acid detergent insoluble nitrogen.

Fraction A of the nitrogenous constituents, which consisted of non-protein $\mathrm{N}$, exhibited a quadratic relationship with SM (Table 6). However, the B1 fraction, which consists of totally degradable albumins and globulins and together with non-protein $\mathrm{N}$ provides the available soluble $\mathrm{N}$ (SNIFFEN et al., 1992), was not significantly affected $(P=0.16)$. When there is adequate availability of fraction $\mathrm{B} 1$ in the rumen at bacteria biomass using non-structural carbohydrates can be increased (RUSSELL et al., 1992). The B2 fraction was significantly affected by SM treatment $(\mathrm{P}=0.08)$, which indicated that less 
degradation of true protein in most SM silages. The B3 fraction as also affected $(\mathrm{P}<0.02)$ and decreased linearly with increasing SM. The mean values found in the present study for the B3 fraction are described below by Sniffen et al. (1992) 16.2\% for silage with 25 to $40 \%$ grains. Fraction C consists of the protein associated with lignin and Maillard products did not differ $(\mathrm{P}=0.24)$ between treatments.

Table 6. Effect of specific mass on the nitrogenous constituents fractions of silage produced from second-season corn in southern Brazil.

\begin{tabular}{|c|c|c|c|c|c|}
\hline \multirow{2}{*}{ Parameter } & \multirow{2}{*}{ Statistics } & \multicolumn{4}{|c|}{ Specific masses $\left(\mathrm{kg} \mathrm{DM} \mathrm{m}^{-3}\right)$} \\
\hline & & 90 & 134 & 172 & 216 \\
\hline \multirow{2}{*}{$\begin{array}{c}\text { Fraction A } \\
(\% \mathrm{TN})\end{array}$} & Mean $\pm \mathrm{SE}$ & $33.6 \pm 3.03$ & $24.7 \pm 1.93$ & $29.0 \pm 3.29$ & $32.7 \pm 1.79$ \\
\hline & Regression & \multicolumn{4}{|c|}{$\hat{\mathrm{Y}}=66.47-0.5291 \cdot \mathrm{SM}+0.00174 \cdot \mathrm{SM}^{2}\left(\mathrm{P}=0.095 ; \mathrm{R}^{2}=30.4\right)$} \\
\hline \multirow{2}{*}{$\begin{array}{c}\text { Fraction B1 } \\
(\% \mathrm{TN})\end{array}$} & Mean \pm SE & $26.4 \pm 0.89$ & $29.8 \pm 0.97$ & $25.4 \pm 0.51$ & $31.0 \pm 1.73$ \\
\hline & Regression & \multicolumn{4}{|c|}{$\hat{\mathrm{Y}}=28.16\left(\mathrm{P}=0.160 ; \mathrm{R}^{2}=13.6\right)$} \\
\hline \multirow{2}{*}{$\begin{array}{c}\text { Fraction B2 } \\
(\% \mathrm{TN})\end{array}$} & Mean \pm SE & $10.6 \pm 2.49$ & $17.5 \pm 2.43$ & $15.8 \pm 3.29$ & $19.1 \pm 3.32$ \\
\hline & Regression & \multicolumn{4}{|c|}{$\hat{\mathrm{Y}}=6.78+0.05857 \cdot \mathrm{SM}\left(\mathrm{P}=0.076 ; \mathrm{R}^{2}=20.8\right)$} \\
\hline \multirow{2}{*}{$\begin{array}{c}\text { Fraction B3 } \\
(\% \mathrm{TN})\end{array}$} & Mean \pm SE & $12.2 \pm 1.76$ & $13.5 \pm 1.57$ & $11.1 \pm 2.67$ & $5.3 \pm 0.68$ \\
\hline & Regression & \multicolumn{4}{|c|}{$\hat{\mathrm{Y}}=19.03-0.05565 \cdot \mathrm{SM}\left(\mathrm{P}=0.018 ; \mathrm{R}^{2}=34.1\right)$} \\
\hline \multirow{2}{*}{$\begin{array}{c}\text { Fraction C } \\
(\% \mathrm{TN})\end{array}$} & Mean \pm SE & $17.3 \pm 1.59$ & $14.5 \pm 2.05$ & $18.6 \pm 3.33$ & $11.9 \pm 0.64$ \\
\hline & Regression & \multicolumn{4}{|c|}{$\hat{\mathrm{Y}}=15.57\left(\mathrm{P}=0.244 ; \mathrm{R}^{2}=9.5\right)$} \\
\hline
\end{tabular}

$\mathrm{DM}=$ Dry matter; $\mathrm{TN}=$ Total nitrogen

\section{Conclusion}

In the present study, differences in the compression (i.e., SM) of corn silages caused changes in the contents of soluble sugar and nitrogenous constituents; however, SM alone did not explain the entire preservation of the ensiled material.

\section{References}

AKINS, M. S.; SHAVER, R. D. Influence of corn silage hybrid type on lactation performance by Holstein dairy cows. Journal of Dairy Science, Champaign, v. 97, n. 12, p. 7811-7820, 2014.

ASSOCIATION OF OFFICIAL ANALYTICAL CHEMISTRY - AOAC. Official methods of analysis. Washington. D.C. 1995. 2000 p.

BERGAMASCHI, H.; MATZENAUER, R. $O$ milho $e o$ clima. Porto Alegre: Emater/RS-Ascar, 2014. 84 p.

BORREANI, G.; DOLCI, P.; TABACCO, E.; COCOLIN, L. Aerobic deterioration stimulates outgrowth of sporeforming Paenibacillus in corn silage stored under oxygen-barrier or polyethylene films. Journal of Dairy Science, Champaign, v. 96, n. 6, p. 5206-5216, 2013.
BORREANI, G.; TABACCO, E. Improving corn silage quality in the top layer of farm bunker silos through the use of a next-generation barrier film with high impermeability to oxygen. Journal of Dairy Science, Champaign, v. 97, n. 4, p. 2415-2426, 2014.

BRUNETTE, T.; BAURHOO, B.; MUSTAFA, F. Replacing corn silage with different forage millet silage cultivars: effects on milk yield, nutrient digestion, and ruminal fermentation of lactating dairy cows. Journal of Dairy Science, Champaign, v. 97, n. 10, p. 6440-6449, 2014.

CABRAL, L. S.; VALADARES FILHO, S. C.; MALAFAIA, P. A. M.; LANA, R. P.; SILVA, J. F. C.; VIEIRA, R. A. M.; PEREIRA, E. S. Frações de carboidratos de alimentos volumosos e suas taxas de degradação estimadas pela técnica de produção de gases. Revista Brasileira de Zootecnia, Viçosa, MG, v. 29, n. 6, p. 2087-2098, 2000. Suplemento 1.

DANNER, H.; HOLZER, M.; MAYRHUBER, E.; BRAUN, R. Acetic acid increases stability of silage under aerobic conditions. Applied and Environmental Microbiology, Washington, v. 69, n. 1, p. 562-567, 2003.

DI MARCO, O. N.; AELLO, M. S.; NOMDEDEU, M.; VAN HOUTTE, S. Effect of maize crop maturity on silage chemical composition and digestibility (in vivo, in situ and in vitro). Animal Feed Science and Technology, Amsterdam, v. 99, n. 1, p. 37-43, 2002. 
EMPRESA BRASILEIRA DE PESQUISA AGROPECUÁRIA - EMBRAPA. Centro Nacional de Pesquisa de Solos. Sistema Brasileiro de Classificação de Solos. Rio de Janeiro: IBGE, 1999. Disponível em: $<$ http://mapas.ibge.gov.br/solos/viewer.htm>. Acesso em: 12 set. 2007.

FERREIRA, J. J. Estágio de maturação ideal para ensilagem do milho e do sorgo. In: CRUZ, J. C.; PEREIRA FILHO, I. A.; RODRIGUES, J. A. S.; FERREIRA, J.J (Ed.) Produção e utilização de silagem de milho e sorgo. Sete Lagoas: Embrapa Milho e Sorgo, 2001. p. 405-428.

GONÇALVES, J. A. G.; ZAMBOM, M. A.; FERNANDES, T.; TININI, R. C. dos R.; SCHIMIDT, E. L.; CASTAGNARA, D. D.; CANABARRO, L. de O.; CRUZ, E. A. Silagem de resíduo da extração de amido da mandioca em substituição ao milho moído da ração para ovinos. Revista Brasileira de Saúde e Produção Animal, Salvador, v. 16, n. 4, p. 839-849, 2015.

HALL, M. B. Neutral detergent-soluble carbohydrates, nutritional relevance and analysis: a laboratory manual. Florida: University of Florida, 2000. 42 p.

HALL, M. B.; LEWIS, B. A.; VAN SOEST, P. J.; CHASE, L. E. A simple method for estimation of neutral detergent-soluble fibre. Journal of the Science of Food and Agriculture, London, v. 74, n. 4, p. 441-449, 1997.

JOBIM, C. C.; NUSSIO, L. G.; REIS, R. A.; SCHMIDT, P. Avanços metodológicos na avaliação da qualidade da forragem conservada. Revista Brasileira de Zootecnia, Viçosa, MG, v. 36, p. 101-119, 2007. Suplemento Especial.

JOBIM, C. C.; PEREIRA, J. R. A.; SANTOS, G. T. Sistemas de produção de leite com ênfase na utilização de volumosos conservados. In: REIS, R. A.; SIQUEIRA, R. A.; BERTIPAGLIA, L. M. A. (Ed.). Volumosos na produção de ruminantes. Jaboticabal: Funep, 2005. p. 61-82.

JOHNSON, L. M.; DAVIDSON, D.; MAHANNA, W. C.; SHINNERS, K.; LINDER, D. Corn silage management: effects of maturity, inoculation, and mechanical processing on pack density and aerobic stability. Journal of Dairy Science, Champaign, v. 85, n. 2, p. 434-444, 2002.

LICITRA, G.; HERNANDEZ, T. M.; VAN SOEST, P. J. Standardization of procedures for nitrogen fractionation of ruminants feeds. Animal Feed Science and Technology, Amsterdam, v. 57, n. 4, p. 347-358, 1996.

MERTENS, D. R. Gravimetric determination of amylasetreated neutral detergent fiber in feeds with refluxing in beakers or crucibles: collaborative study. Journal of AOAC International, Arlington, v. 85, n. 6, p. 1211-1240, 2002.

MORO, J. G.; JOBIM, C. C.; KRÜGER, A. M.; SILVA, M. J. S. da; OLIVEIRA, T. M. Composição nutricional de milho Bt ensilado com inoculante enzimo bacteriano e avaliado em ovinos. Arquivo Brasileiro de Medicina Veterinária e Zootecnia, Belo Horizonte, v. 67, n. 3, p. 864-872, 2015.

MUCK, R. E.; BOLSEN, K. K. Silage preservation and silage additive products. In: BOLSEN, K. K. (Ed.) Field guide for hay and silage management in North America. NFIA, 1991. p. 105-126.

NATIONAL RESEARCH COUNCIL - NRC. Nutrient of requirements of dairy cattle. $7^{\text {th }}$ ed. Washington: National Academic Press, 2001. 381 p.

NEUMANN, M.; MÜHLBACH, P. R. F.; NÖRNBERG, J. L.; OST, P. R.; RESTLE, J.; SANDINI, I. E.; ROMANO, M. A. Características da fermentação da silagem obtida em diferentes tipos de silo sob efeito do tamanho de partícula e da altura de colheita das plantas de milho. Ciência Rural, Santa Maria, v. 37, n. 3, p. 847854, 2007.

RABELO, C. H. S.; REZENDE, A. V.; RABELO, F. H. S.; NOGUEIRA, D. A.; SENEDESE, S. S.; VIEIRA, P. de F.; BERNARDES, C. L.; CARVALHO, A. Silagens de milho inoculadas microbiologicamente em diferentes estádios de maturidade: perdas fermentativas, composição bromatológica e digestibilidade in vitro. Ciência Rural, Santa Maria, v. 44, n. 2, p. 368-373, 2014.

RUSSELL, J. B.; O'CONNOR, J. D.; FOX, D. G.; VAN SOEST, P. J.; SNIFFEN, C. J. A net carbohydrate and protein system for evaluating cattle diets: I. ruminal fermentation. Journal of Animal Science, Champaign, v. 70, n. 11, p. 3551-3561, 1992.

SENGER, C. C. D.; MÜHLBACH, P. R. F.; SÁNCHEZ, L. M. B.; NETTO, D. P.; LIMA, L. D. Composição química e digestibilidade in vitro de silagens de milho com distintos teores de umidade e níveis de compactação. Ciência Rural, Santa Maria, v. 35, n. 6, p. 1393-1399, 2005.

SNIFFEN, C. J.; O'CONNOR, J. D.; VAN SOEST, P. J.; FOX, D. G.; RUSSELL, J. B. A net carbohydrate and protein system for evaluating cattle diets: carbohydrate and protein availability. Journal of Animal Science, Champaign, v. 70, n. 11, p. 3562-3577, 1992.

STATISTICAL ANALYSIS SYSTEM - SAS. Statistical analysis system user's guide. Cary: Statistics Cary SAS Institute, 2001. 
TRES, T. T.; JOBIM, C. C.; PINTO, R. J. B.; SOUZA NETO, I. L. de; SCAPIM, C. A.; SILVA, M. S. J. da. Composição nutricional e digestibilidade in vitro de genótipos de milho produzidos em dois anos agrícolas. Semina: Ciências Agrárias, Londrina, v. 35, n. 6, p. 3249-3262, 2014.

VAN GASTELEN, S.; ANTUNES-FERNANDES, E. C.; HETTINGA, K. A.; KLOP, G.; ALFERINK, S. J. J.; HENDRIKS, W. H.; DIJKSTRA, J. Enteric methane production, rumen volatile fatty acid concentrations, and milk fatty acid composition in lactating Holstein-Friesian cows fed grass silage- or corn silage-based diets. Journal of Dairy Science, Champaign, v. 98, n. 3, p. 1915-1927, 2015.

VAN SOEST, P. J. Nutritional ecology of the ruminant. Ithaca: Cornell University Press, 1994. 476 p.

VELHO, J. P.; MÜHLBACH, P. R. F.; GENRO, T. C. M.; HAYGERT-VELHO, I. M. P.; NÖRNBERG, J. L.; ORQIS, M. G.; KESSLER, J. D. Alterações bromatológicas nas frações dos carboidratos de silagens de milho safrinha sob diferentes tempos de exposição ao ar antes da ensilagem. Revista Brasileira de Zootecnia, Viçosa, MG, v. 35, n. 4, p. 1621-1628, 2006. Suplemento.

VELHO, J. P.; MÜHLBACH, P. R. F.; NÖRNBERG, J. L.; GENRO, T. C. M.; SANCHEZ, L. M. B.; HAYGERTVELHO, I. M. P.; KESSLER, J. D. Frações nitrogenadas de silagens de milho safrinha sob diferentes tempos de exposição ao ar antes da ensilagem. Ciência Rural, Santa Maria, v. 38, n. 1, p. 166-172, 2008.

VELHO, J. P.; MÜHLBACH, P. R. F.; NÖRNBERG, J. L.; VELHO, I. M. P. H.; GENRO, T. C. M.; KESSLER, J. D. Composição bromatológica de silagens de milho produzidas com diferentes densidades de compactação. Revista Brasileira de Zootecnia, Viçosa, MG, v. 36, n. 5, p. 1532-1538, 2007.

WALKER, A. R. P. Does the dietary fiber hypothesis really work? Cereal Foods World, Minneapolis, v. 38, n. 3, p. 128-134, 1993. 
